\title{
Seed quality of Amburana cearensis (Allemão) A.C. Sm. (Fabaceae) is influenced by storage condition ${ }^{1}$
}

\author{
Marcelo do Nascimento Araujo $2^{*}$, Marisol Ferraz ${ }^{2}$, \\ Fabiana Karla Araújo Américo ${ }^{2}$, Fabrício Francisco Santos Silva ${ }^{2}$, \\ Bárbara França Dantas ${ }^{3}$, Claudineia Regina Pelacani Cruz ${ }^{2}$
}

\begin{abstract}
The aim of this study was to evaluate the effects of storage conditions on the germination of $A$. cearensis seeds. The experimental design was completely randomized into split plots over time with four replicates. The storage conditions of the airtight containers in the refrigerator and laboratory, paper bags in the laboratory and liquid nitrogen were assessed for 27 months. In the laboratory, we evaluated the germination, the germination rate, uniformity of germination, and total soluble and reducing sugars in the radicle. In the greenhouse, we evaluated seedling emergence, emergence rate and height of 30-day-old seedlings. Seeds stored in the refrigerator maintained a high initial germination rate, which decreased from the $21^{\text {st }}$ month. Seeds stored in paper bags in the laboratory showed low emergence and small seedlings. Total soluble sugars and reducing sugars were mobilized when the seeds were stored at low temperatures. Thus, it is not advisable to store $A$. cearensis seeds in a laboratory environment without airtight containers. A. cearensis seeds kept in a refrigerated environment maintained their viability for at least two years.
\end{abstract}

Index terms: caatinga, conservation, emergence, Leguminosae, umburana-de-cheiro.

\section{A qualidade de sementes de Amburana cearensis (Allemão) A.C. Sm. (Fabaceae) é influenciada pelas condições de armazenamento}

\begin{abstract}
RESUMO- O objetivo deste trabalho foi avaliar os efeitos das condições de armazenamento sobre a germinação de sementes de A. cearensis. O delineamento experimental foi inteiramente casualizado em parcelas subdivididas ao longo do tempo com quatro repetições. As condições de armazenamento como recipiente hermético no refrigerador; recipiente hermético em laboratório, sacos de papel em laboratório e nitrogênio líquido foram avaliadas durante 27 meses. No laboratório foram avaliadas germinação, taxa de germinação, uniformidade de germinação, açúcares solúveis totais e redutores da radícula. Em casa de vegetação avaliou-se emergência das plântulas, taxa de emergência e altura de mudas no decorrer dos 30 dias. As sementes armazenadas no refrigerador mantiveram alta germinação inicial e diminuíram a partir do $21^{\circ}$ mês. O armazenamento de sementes em sacos de papel em laboratório apresentou baixa emergência e menores mudas. Os açúcares solúveis totais e os açúcares redutores são mobilizados quando as sementes são armazenadas a baixas temperaturas. Não é aconselhável armazenar sementes de $A$. cearensis em ambiente de laboratório sem um recipiente hermético. As sementes de $A$. cearensis mantidas em ambiente refrigerado mantêm a viabilidade durante pelo menos dois anos.
\end{abstract}

Termos para indexação: caatinga, conservação, emergência, Leguminosae, umburana-de-cheiro.

\section{Introduction}

The Caatinga biome (Brazilian semi-arid vegetation) has a significant biological diversity compared with other semi-arid regions of the world. This biodiversity is extremely important for local communities to which this biome provides

\footnotetext{
${ }^{1}$ Submitted on 05/02/2017. Accepted for publication on 08/07/2017.

${ }^{2}$ Departamento de Ciências Biológicas Universidade Estadual de Feira de Santana, Caixa Postal 252, 44036-900 - Feira de Santana, BA, Brasil.
}

timber, food, medicine and forage (Loiola et al., 2012; Santos et al., 2011; Santos et al., 2010). Uncontrolled exploitation of natural resources of Caatinga has caused severe degradation of vegetation, mainly because of deforestation due to agricultural activities, without allowing species regeneration or reforestation (Farias et al., 2013).

\footnotetext{
${ }^{3}$ Embrapa Semiárido, Caixa Postal 23, 56300-970 - Petrolina, PE, Brasil. *Corresponding author <dr.marcelo_araujo@outlook.com>
} 
This region's climate presents average temperatures of approximately $26{ }^{\circ} \mathrm{C}$, with little annual variation and rainfall lower than 750 millimetres per year (Costa et al., 2007). The vegetation is conditioned to water deficit throughout the year, which is mainly related to stochastic rainfall events associated with high temperatures and high light intensity, which cause a high evaporative demand and consequent desiccation of the soil (Trovão et al., 2007). This climatic instability, together with human occupation, threatens the native biodiversity of Caatinga (Leal et al., 2005; Lima-Araújo et al., 2007). A significant part of Caatinga has suffered from drought since 2011 (Leivas et al., 2014), leading to lower seedling recruitment, the death of adult trees and loss of biodiversity.

The Amburana cearensis tree is native to South-America, typical of the Caatinga biome and often explored by local populations for its medicinal potential, leading this species to extinction (Pimentel and Guerra, 2010). It is known for its medicinal properties: the bark and seeds are used to produce popular medications to treat pulmonary diseases, cough, asthma, bronchitis and whooping cough (Maia, 2008). Therefore, A. cearensis is currently listed in the global IUCN list as an endangered species and was listed in the Brazilian national list of endangered species until 2015 (Americas Regional Workshop, 1998).

Seed deterioration is inevitable, even when seeds are placed in appropriate preservation environments (Arjmand et al., 2014). Factors such as temperature and humidity can influence the process of seed deterioration during storage (Moncaleano-Escandon et al., 2013). Therefore, it is imperative to ascertain, for all species, efficient methods and conditions to store seeds to maintain their viability. Thus, in endangered species, there is an urgent need to determine seed conservation strategies that involve the maintenance of a high level of seed germination, seedling establishment and the preservation of their physiological potential during seed storage. Some studies have reported alternative storage conditions for Caatinga species seeds such as the use of plastic containers in a dry chamber and freezer environments for Caesalpinia pyramidalis (Oliveira et al., 2012); paper, cotton, plastic or aluminium foil bags maintained in a refrigerator or freezer for Myracrodruon urundeuva seeds (Guedes et al., 2012); and maintenance of seeds inside the fruits of Caesalpinia leiostachya (Biruel et al., 2007). However, all of the methods mentioned above show oscillations in seed vigour due to different methods of packing seeds for storage.

To maintain the quality of stored seeds, factors such as seed moisture and storage temperature are important. Although the seed quality cannot be improved during the storage period, it can be maintained for a long period (Zuchi et al., 2013).
Moreover, to better understand seed behaviour in storage, it is essential to verify factors such as tolerance of these species to low temperatures. Thus, this study aimed to evaluate the quality of $A$. cearensis seeds in different storage conditions.

\section{Material and Methods}

Amburana cearensis seeds used in this experiment were harvested in the Caatinga biome in Lagoa Grande, state of Pernambuco (S 8³4'04,00"; O 040'10'18,00"; Figure 1), from dehiscent fruits in August 2013. Fresh seeds were readily evaluated for seed quality and were compared with the stored seeds.

Seed storage: Seeds were stored in four different conditions including craft paper bags enclosed in airtight containers in refrigerator $\left(4 \pm 3{ }^{\circ} \mathrm{C}, 60 \pm 4 \% \mathrm{RH}\right)$, craft paper bags enclosed in airtight container in a laboratory environment $\left(25 \pm 4{ }^{\circ} \mathrm{C}\right.$, $19 \pm 3 \% \mathrm{RH})$, craft paper bags in laboratory environment $\left(25 \pm 4{ }^{\circ} \mathrm{C}, 56 \pm 6 \% \mathrm{RH}\right)$ and polypropylene tubes in liquid nitrogen $\left(-196{ }^{\circ} \mathrm{C}\right)$. The seeds remained in these conditions for 27 months. Seed samples were removed from each storage condition to evaluate seed quality. Temperature and relative humidity were monitored with a data logger: Hobo data logger - model U10-003. The experimental design was completely randomized in split-plots along time, with four replicates. Four different storage conditions were considered as plots and the storage time was considered as sub plots.

Before storage, all seeds were put in a container with silica gel for $60 \mathrm{~min}$ to standardize the water content at approximately 9\%. Seeds in cryopreservation were placed in Falcon tubes in a container with liquid nitrogen. Seeds removed from liquid nitrogen were immediately placed in a refrigerator $\left(5 \pm 3{ }^{\circ} \mathrm{C}\right.$, $60 \pm 4 \%$ UR) for $60 \mathrm{~min}$, allowing gradual thawing and relative rewarming of samples (Pritchard and Nadarajan, 2008).

To evaluate the quality of fresh and stored seeds, four replicates of 25 seeds were used in germination and seedling emergence tests and quantifying sugar metabolism in germinating seeds during 27 months.

Water content: The water content was determined by the oven method at $105 \pm 3{ }^{\circ} \mathrm{C}$ for 24 hours, using two samples of 10 seeds and the results were expressed as a percentage based on the seed fresh weight (Brasil, 2013).

Germination test: Were carried out on germination paper soaked with distilled water at a proportion of 2.5 times the dry paper weight. Seeds were germinated in a BOD chamber at $30{ }^{\circ} \mathrm{C}$ with a 12-hour photoperiod (Brasil, 2013). Seed germination scoring was performed daily until seedling establishment, which occurred after approximately 15 days. The seeds were considered as germinated at $1 \mathrm{~mm}$ radicle emergence. 

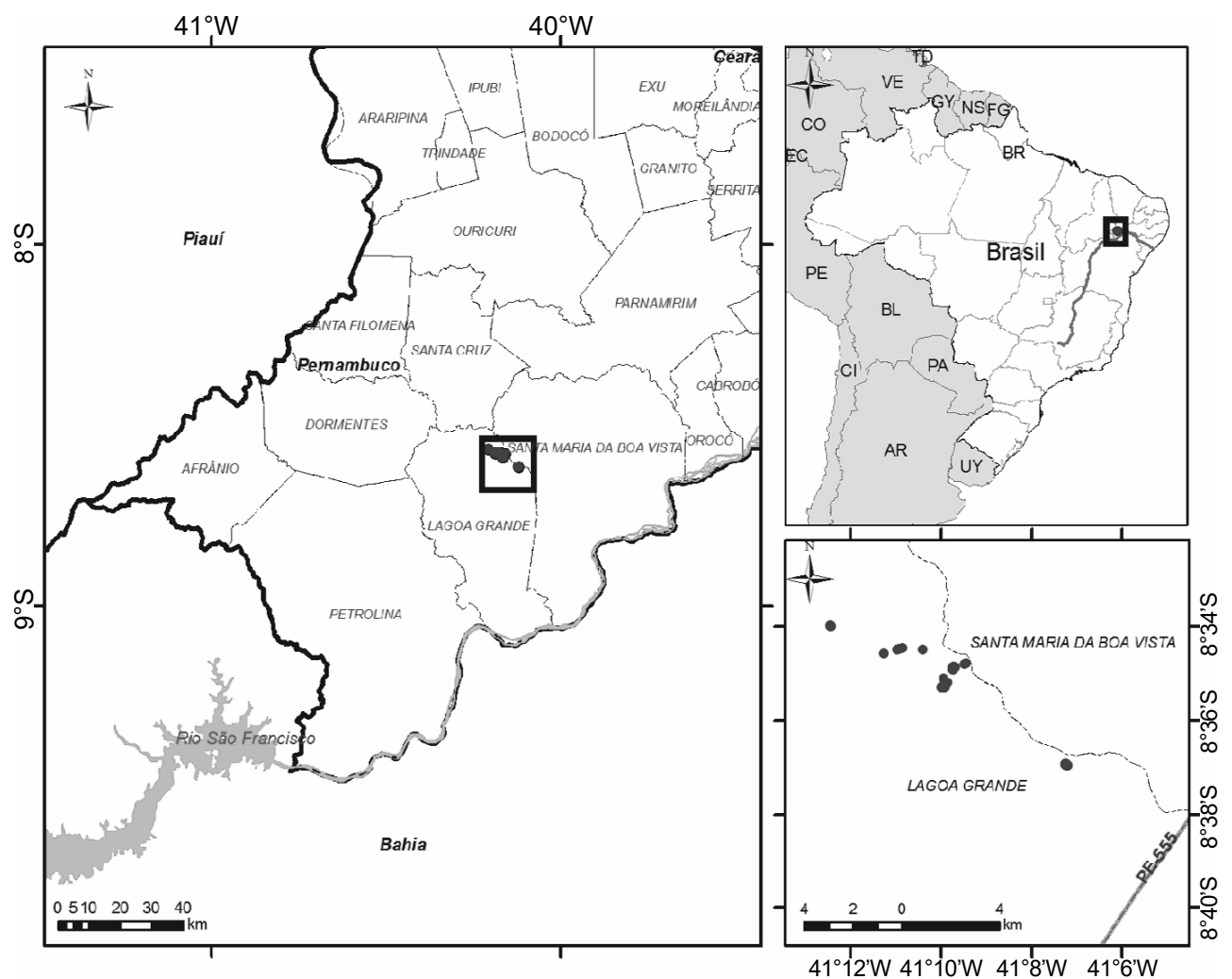

Figure 1. Map of the collecting area (square) in Lagoa Grande / Pernambuco state in Brazil (Made by: Lab Geoprocessing and remote sensing EMBRAPA Semiárido).

Final germination (FG, \%); germination uniformity (GU; time elapsed between $20 \%$ and $80 \%$ germination, days ${ }^{-2}$ ) and germination rate (reciprocal of time to reach $50 \%$ of final germination, GR, days ${ }^{-1}$ ) were also estimated (Toorop et al., 2012).

Seedling emergence test: These tests were performed by sowing fresh and stored seeds in polystyrene trays containing the commercial substrate Plantmax ${ }^{\circledR}$ and arranging the trays in a greenhouse with a controlled environment (40\% luminosity with black shading screens and manual irrigation according to plant requirements). The emergence was evaluated daily for 30 days (Brasil, 2013), and final emergence (FE, \%), emergence rate (reciprocal of time to reach $50 \%$ of final emergence, ER, days ${ }^{-1}$ ) and average 30 days seedling height (SH) were calculated.

Total soluble sugars and reducing sugars quantification: The extractions were performed by grinding a $0.5 \mathrm{~g}$ root sample (c. 10 seedlings) in a sterile mortar with $10 \mathrm{~mL}$ of distilled water. The mixture was centrifuged at $3.000 x \mathrm{~g}$ for 20 minutes without refrigeration. The supernatant was collected to microtubes and kept in a freezer at $-20^{\circ} \mathrm{C}$ until reducing sugars (Miller, 1959) and total soluble sugars (Morris, 1948; Yemm and Willis, 1954) assays. Four replicates of each sample were maintained.
Statistical analysis: Data were tested for normality and homogeneity of variance before comparing means using the Shapiro-Wilk and Levene's tests, both at 0.05 probability level. Non-normal percentage data were arcsine-transformed and re-tested. Continuing non-normal data were analysed by the non-parametric Kruskal-Wallis test at 0.05 probability level. For normal data, the Tukey test was used at 0.05 probability level. Fresh seeds were compared with stored seeds by the Dunnett (normal data) and Kruskal-Wallis (non-normal data) tests at 0.05 probability level.

\section{Results and Discussions}

A. cearensis seeds showed an initial water content of $9.2 \%$, which did not change during storage, regardless of the conditions.

Germination (FG), germination rate (GR), emergence (FE), emergence rate (ER) and total soluble sugars (TSS) data were not normally distributed and/or were not homogeneous, and therefore, the media test used was Kruskal-Wallis.

Storage conditions influenced the germination behaviour of $A$. cearensis seeds. Seeds from the laboratory environment packed only in paper bags showed decreased FG in the $27^{\text {th }}$ 
month differing statistically from fresh seeds and 6-months of storage. Seeds kept in airtight containers in the refrigerator and laboratory did not show germination differences compared to fresh seeds over time. Seeds stored in liquid nitrogen showed different FG compared with fresh seeds and storage conditions with airtight container in the $24^{\text {th }}$ month (Table 1 ).

Amburana cearensis seeds kept in the laboratory without a container showed decreased GR (high-speed germination), and this difference was statistically significant compared with seeds kept in airtight containers in the laboratory in the $27^{\text {th }}$ month of storage. Except for the $12^{\text {th }}$ month, the seeds stored in the laboratory without a container (which can be attributed to an outlier) did not show differences in GR compared with fresh seeds. Moreover, there were differences between seeds stored in the laboratory without a container and those in liquid nitrogen $\left(\mathrm{N}_{2}\right)$ container at 6 and 12 months (Table 2).

The GU of seeds in liquid nitrogen differed from that of fresh seeds as of $12^{\text {th }}$ month and showed slow germination, which was twice as slow compared with that of fresh seeds (Table 3).

FE percentage in the greenhouse conditions for $A$. cearensis stored seeds showed that the refrigerator-stored seeds maintained their vigour in comparison to fresh seeds and over storage time. Seeds stored in the laboratory environment, packed in paper bags and in a liquid nitrogen container showed lower FE percentage than fresh seeds in the $21^{\text {st }}$ month of storage. Following similar behaviour, A. cearensis seeds stored in airtight containers in a laboratory environment showed a reduction in the values in the $21^{\text {st }}$ month of storage and showed differences compared to fresh seeds in the $24^{\text {th }}$ and $27^{\text {th }}$ months (Table 4).

Regarding ER and seedlings height (SH) of stored seeds in the laboratory without a container, the latter two storage evaluations were different compared with fresh seeds and the former two storage evaluations (Tables 5 and 6). We also noticed this trend in the SH of seeds kept in a container in the laboratory (Table 6). There were also significant losses

Table 1. Final germination (\%) of A. cearensis seeds in different storage conditions and times of storages.

\begin{tabular}{|c|c|c|c|c|}
\hline \multirow{2}{*}{$\begin{array}{l}\text { Time Storage } \\
\text { (Months) }\end{array}$} & \multicolumn{4}{|c|}{ Storage conditions } \\
\hline & $\begin{array}{l}\text { Airtight container } \\
\text { in Refrigerator }\end{array}$ & $\begin{array}{c}\text { Airtight container } \\
\text { in Laboratory }\end{array}$ & $\begin{array}{c}\text { Laboratory without } \\
\text { container }\end{array}$ & $\begin{array}{l}\text { Liquid nitrogen } \\
\left(\mathrm{N}_{2}\right) \text { container }\end{array}$ \\
\hline 0 & 98.0 & & & \\
\hline 6 & $90.0 \mathrm{Aa}$ & $87.5 \mathrm{Aa}$ & $98.0 \mathrm{Aa}$ & $87.0 \mathrm{Aa}$ \\
\hline 9 & $93.0 \mathrm{Aa}$ & $93.0 \mathrm{Aa}$ & 93.0 Aab & $83.0 \mathrm{Aa}$ \\
\hline 12 & $94.0 \mathrm{Aa}$ & $91.0 \mathrm{Aa}$ & $94.0 \mathrm{Aab}$ & $87.0 \mathrm{Aa}$ \\
\hline 21 & $92.7 \mathrm{Aa}$ & $90.0 \mathrm{Aa}$ & 82.0 Aab & $85.0 \mathrm{Aa}$ \\
\hline 24 & $94.0 \mathrm{Aa}$ & $95.0 \mathrm{Aa}$ & 83.0 ABab & $\cdot 72.0 \mathrm{Ba}$ \\
\hline 27 & $90.7 \mathrm{Aa}$ & $90.0 \mathrm{Aa}$ & $\cdot 76.0 \mathrm{Ab}$ & $90.0 \mathrm{Aa}$ \\
\hline
\end{tabular}

$\mathrm{CV} \%=7.70 ; \mathrm{W}=0.98 \mathrm{~ns} ; \mathrm{F}=2.29 * *$

Means followed by the same capital letters in the line and lowercase on the column do not differ by Kruskal-Wallis ranking values at $5 \%$ probability. Means followed by $\bullet$ differ from the initial time (fresh seeds) by Kruskal-Wallis test at $5 \%$ probability. W; F: statistics of Shapiro-Wilk and Levene's test respectively indicate residue with normal distribution and variance. ns and $* *=$ not significant and significant at $1 \%$, respectively.

Table 2. Germination rate ( days $\left.^{-1}\right)$ of $A$. cearensis seeds in different storage conditions and times of storage.

\begin{tabular}{|c|c|c|c|c|}
\hline \multirow[b]{2}{*}{$\begin{array}{l}\text { Time Storage } \\
\text { (Months) }\end{array}$} & \multicolumn{4}{|c|}{ Storage conditions } \\
\hline & $\begin{array}{l}\text { Airtight container } \\
\text { in Refrigerator }\end{array}$ & $\begin{array}{l}\text { Airtight container } \\
\text { in Laboratory }\end{array}$ & $\begin{array}{c}\text { Laboratory without } \\
\text { container }\end{array}$ & $\begin{array}{c}\text { Liquid nitrogen }\left(\mathrm{N}_{2}\right) \\
\text { container }\end{array}$ \\
\hline 0 & 0.188 & & & \\
\hline 6 & $0.154 \mathrm{ABa}$ & $0.150 \mathrm{ABa}$ & $0.185 \mathrm{Aab}$ & $0.143 \mathrm{Ba}$ \\
\hline 9 & $0.155 \mathrm{Aa}$ & $0.181 \mathrm{Aa}$ & $0.195 \mathrm{Aab}$ & $0.173 \mathrm{Aa}$ \\
\hline 12 & $0.174 \mathrm{ABa}$ & $0.198 \mathrm{ABa}$ & $\bullet 0.236 \mathrm{Aa}$ & $0.162 \mathrm{Ba}$ \\
\hline 21 & $0.152 \mathrm{Aa}$ & $0.153 \mathrm{Aa}$ & $0.150 \mathrm{Aab}$ & $0.164 \mathrm{Aa}$ \\
\hline 24 & $0.170 \mathrm{Aa}$ & $0.171 \mathrm{Aa}$ & $0.147 \mathrm{Ab}$ & $0.144 \mathrm{Aa}$ \\
\hline 27 & $0.170 \mathrm{ABa}$ & $0.177 \mathrm{Aa}$ & $0.130 \mathrm{Bb}$ & $0.142 \mathrm{ABa}$ \\
\hline
\end{tabular}

$\mathrm{CV} \%=10.28 ; \mathrm{W}=0.97 * ; \mathrm{F}=1.87 *$

Means followed by the same capital letters in the line and lowercase on the column do not differ by Kruskal-Wallis ranking values at $5 \%$ probability. Means followed by $\bullet$ differ from the initial time (fresh seeds) by Kruskal-Wallis test at $5 \%$ probability. W; F: statistics of Shapiro-Wilk and Levene's test respectively indicate residue with normal distribution and variance. $*=$ significant at $5 \%$. 
Table 3. Germination uniformity $\left(\mathrm{day}^{-1}\right)$ of $A$. cearensis seeds in different storage conditions and times of storage.

\begin{tabular}{|c|c|c|c|c|}
\hline \multirow[b]{2}{*}{$\begin{array}{l}\text { Time storage } \\
\text { (Months) }\end{array}$} & \multicolumn{4}{|c|}{ Storage conditions } \\
\hline & $\begin{array}{l}\text { Airtight container in } \\
\text { Refrigerator }\end{array}$ & $\begin{array}{l}\text { Airtight container in } \\
\text { Laboratory }\end{array}$ & $\begin{array}{l}\text { Laboratory without } \\
\text { container }\end{array}$ & $\begin{array}{l}\text { Liquid nitrogen }\left(\mathrm{N}_{2}\right) \\
\text { container }\end{array}$ \\
\hline 0 & 2.53 & & & \\
\hline 6 & $3.61 \mathrm{Aa}$ & $3.69 \mathrm{Aa}$ & $2.62 \mathrm{Aa}$ & $3.70 \mathrm{Aa}$ \\
\hline 9 & $4.36 \mathrm{Aa}$ & $3.45 \mathrm{Aa}$ & $3.53 \mathrm{Aa}$ & $3.96 \mathrm{Aa}$ \\
\hline 12 & $3.85 \mathrm{Aa}$ & $3.24 \mathrm{Aa}$ & $1.95 \mathrm{Aa}$ & $\cdot 5.18 \mathrm{Aa}$ \\
\hline 21 & $4.34 \mathrm{Aa}$ & $3.57 \mathrm{Aa}$ & $2.82 \mathrm{Aa}$ & $\cdot 5.10 \mathrm{Aa}$ \\
\hline 24 & $3.60 \mathrm{Aa}$ & $3.04 \mathrm{Aa}$ & $3.19 \mathrm{Aa}$ & •4.87 Aa \\
\hline 27 & $4.07 \mathrm{Aa}$ & $2.46 \mathrm{Aa}$ & $3.70 \mathrm{Aa}$ & •4.96 Aa \\
\hline
\end{tabular}

$\mathrm{CV} \%=23.80 ; \mathrm{W}=0.99 \mathrm{~ns} ; \mathrm{F}=1.39 \mathrm{~ns}$

Means followed by the same capital letters in the line and lowercase on the column do not differ by Tukey test at $5 \%$ probability. Means followed by $\bullet$ differ from the initial time (fresh seeds) by Dunnett test at 5\% probability. W; F: statistics of Shapiro-Wilk and Levene's test respectively indicate residue with normal distribution and variance. $\mathrm{ns}=$ not significant.

Table 4. Final emergence (\%) of A. cearensis seeds in different storage conditions and times of storage.

\begin{tabular}{|c|c|c|c|c|}
\hline \multirow{2}{*}{$\begin{array}{l}\text { Time storage } \\
\text { (Months) }\end{array}$} & \multicolumn{4}{|c|}{ Storage conditions } \\
\hline & $\begin{array}{l}\text { Airtight container in } \\
\text { Refrigerator }\end{array}$ & $\begin{array}{l}\text { Airtight container in } \\
\text { Laboratory }\end{array}$ & $\begin{array}{l}\text { Laboratory without } \\
\text { container }\end{array}$ & $\begin{array}{l}\text { Liquid nitrogen }\left(\mathrm{N}_{2}\right) \\
\text { container }\end{array}$ \\
\hline 0 & 81.25 & & & \\
\hline 6 & $80.0 \mathrm{Aa}$ & $62.5 \mathrm{ABa}$ & $43.7 \mathrm{Ba}$ & $56.7 \mathrm{ABa}$ \\
\hline 9 & $77.5 \mathrm{Aa}$ & $61.2 \mathrm{Aa}$ & $48.8 \mathrm{Aa}$ & $56.7 \mathrm{Aa}$ \\
\hline 12 & $77.5 \mathrm{Aa}$ & $72.5 \mathrm{Aa}$ & $48.7 \mathrm{Aa}$ & $63.7 \mathrm{Aa}$ \\
\hline 21 & $64.4 \mathrm{Aa}$ & $\cdot 31.4 \mathrm{Aa}$ & $\cdot 30.5 \mathrm{Aa}$ & $\cdot 35.0 \mathrm{Aa}$ \\
\hline 24 & $65.7 \mathrm{Aa}$ & $40.0 \mathrm{ABa}$ & $\cdot 21.5 \mathrm{Ba}$ & •38.7 ABa \\
\hline 27 & $63.0 \mathrm{Aa}$ & $\cdot 35.0 \mathrm{ABa}$ & $\cdot 20.0 \mathrm{Ba}$ & •33.7 ABa \\
\hline
\end{tabular}

$\mathrm{CV} \%=25.16 ; \mathrm{W}=0.97 * ; \mathrm{F}=2.04 *$

Means followed by the same capital letters in the line and lowercase on the column do not differ by Kruskal-Wallis ranking values at $5 \%$ probability. Means followed by $\bullet$ differ from the initial time (fresh seeds) by Kruskal-Wallis test at 5\% probability. W; F: statistics of Shapiro-Wilk and Levene's test respectively indicate residue with normal distribution and variance. ${ }^{*}=$ significant at $5 \%$.

Table 5. Emergence rate $\left(\right.$ days $\left.^{-1}\right)$ of $A$. cearensis seeds in different storage conditions and times of storage.

\begin{tabular}{|c|c|c|c|c|}
\hline \multirow{2}{*}{$\begin{array}{l}\text { Time Storage } \\
\text { (Months) }\end{array}$} & \multicolumn{4}{|c|}{ Storage conditions } \\
\hline & $\begin{array}{c}\text { Airtight container in } \\
\text { Refrigerator }\end{array}$ & $\begin{array}{l}\text { Airtight container in } \\
\text { Laboratory }\end{array}$ & $\begin{array}{c}\text { Laboratory without } \\
\text { container }\end{array}$ & $\begin{array}{c}\text { Liquid nitrogen }\left(\mathrm{N}_{2}\right) \\
\text { container }\end{array}$ \\
\hline 0 & 0.0668 & & & \\
\hline 6 & $0.0660 \mathrm{ABa}$ & $0.0698 \mathrm{ABab}$ & $0.0720 \mathrm{Aa}$ & $0.0623 \mathrm{Ba}$ \\
\hline 9 & $0.0679 \mathrm{Aa}$ & $0.0728 \mathrm{Aa}$ & $0.0741 \mathrm{Aa}$ & $0.0681 \mathrm{Aa}$ \\
\hline 12 & $0.0597 \mathrm{Aa}$ & $0.0594 \mathrm{Ab}$ & $0.0585 \mathrm{Aab}$ & $\bullet 0.0552 \mathrm{Aab}$ \\
\hline 21 & $0.0628 \mathrm{Aa}$ & $0.0594 \mathrm{Aab}$ & $0.0585 \mathrm{Aab}$ & $0.0650 \mathrm{Aab}$ \\
\hline 24 & $0.0560 \mathrm{Aa}$ & $0.0561 \mathrm{Aab}$ & $\cdot 0.0485 \mathrm{Bb}$ & $0.0581 \mathrm{Ab}$ \\
\hline 27 & $0.0571 \mathrm{ABa}$ & $0.0594 \mathrm{Aab}$ & $\bullet 0.0487 \mathrm{Bb}$ & $0.0596 \mathrm{ABb}$ \\
\hline
\end{tabular}

Means followed by the same capital letters in the line and lowercase on the column do not differ by Kruskal-Wallis ranking values at $5 \%$ probability. Means followed by $\bullet$ differ from the initial time (fresh seeds) by Kruskal-Wallis test at $5 \%$ probability. W; F: statistics of Shapiro-Wilk and Levene's test respectively indicate residue with normal distribution and variance. $*$ = significant at $5 \%$. 
in SH between months 9 and 12 for seeds maintained in the laboratory environment (with and without airtight container).

In all storage conditions, the roots of $A$. cearensis seedlings showed a slight decrease in TSS content until the $21^{\text {st }}$ month, with lower values followed by an increase up to the last evaluation month. Among all storage conditions, no differences were observed in the levels of TSS in stored seeds compared to fresh seeds (Table 7).

Seeds in liquid $\mathrm{N}_{2}$ also differed in ER and $\mathrm{SH}$ compared with the two former storage evaluations. However, the differences in ER were observed only in the $12^{\text {th }}$ month, and the latest storage evaluation of $\mathrm{SH}$ differed from that of the fresh seeds (Tables 5 and 6).

Reducing sugars (RS) content in the liquid nitrogen stored seeds reached higher values at 21 months of storage compared with roots of fresh seeds and seeds stored in the laboratory without a container (determined by Dunnett's test). The RS content of the roots of seeds stored in the laboratory without container showed significantly lower values in the $12^{\text {th }}$ month compared with the former two storage evaluations (Table 8).

Seeds of $A$. cearensis support a water content as low as $5.27 \%$ (Lúcio et al., 2016) during storage; thus, they have an orthodox behaviour that allows their storage for a long period of low temperatures and relative humidity (Galíndez et al., 2015), with a reduced respiratory rate (Nascimento, 2009). The water content of $A$. cearensis seeds in this study was the same (9.2\%) in all storage environments. Guedes et al. (2010) observed values ranging from 6.25 to $15.89 \%$ in seeds kept in the laboratory and 6.31 to $9.52 \%$ in seeds stored in the refrigerator; the worst emergence values were attributed to a high water content.

Storage method in a laboratory environment without an airtight container reduced the FG and GR compared with the fresh seeds and those stored in the laboratory in airtight containers respectively. Irrespective of the differences in FG and GR, A. cearensis seed germination was higher than $70 \%$

Table 6. Seedling height $\left(\mathrm{cm}^{-1}\right)$ of $A$. cearensis seeds under different storage conditions and times of storage.

\begin{tabular}{|c|c|c|c|c|}
\hline \multirow{2}{*}{$\begin{array}{l}\text { Time Storage } \\
\text { (Months) }\end{array}$} & \multicolumn{4}{|c|}{ Storage conditions } \\
\hline & $\begin{array}{l}\text { Airtight container in } \\
\text { Refrigerator }\end{array}$ & $\begin{array}{l}\text { Airtight container in } \\
\text { Laboratory }\end{array}$ & $\begin{array}{c}\text { Laboratory without } \\
\text { container }\end{array}$ & $\begin{array}{l}\text { Liquid nitrogen }\left(\mathrm{N}_{2}\right) \\
\text { container }\end{array}$ \\
\hline 0 & 12.4 & & & \\
\hline 6 & $10.8 \mathrm{Bb}$ & 12.9 Aab & 12.9 Aab & $12.5 \mathrm{Aab}$ \\
\hline 9 & $13.8 \mathrm{Aa}$ & 14.1 Aa & $14.6 \mathrm{Aa}$ & $14.4 \mathrm{Aa}$ \\
\hline 12 & $12.3 \mathrm{Aab}$ & $11.1 \mathrm{Abc}$ & $12.0 \mathrm{Ab}$ & $11.5 \mathrm{Abc}$ \\
\hline 21 & 12.1 Aab & 12.9 Aab & $11.2 \mathrm{Ab}$ & 12.8 Aab \\
\hline 24 & $10.7 \mathrm{Ab}$ & $\bullet 9.4 \mathrm{ABc}$ & $\cdot 7.8 \mathrm{Bc}$ & $10.6 \mathrm{Abc}$ \\
\hline 27 & $11.1 \mathrm{Ab}$ & $\bullet 9.8 \mathrm{ABc}$ & $\bullet 8.1 \mathrm{Bc}$ & $\bullet 9.9 \mathrm{ABc}$ \\
\hline
\end{tabular}

$\mathrm{CV} \%=9.60 ; \mathrm{W}=0.98 \mathrm{~ns} ; \mathrm{F}=1.49 \mathrm{~ns}$

Means followed by the same capital letters in the line and lowercase on the column do not differ by Tukey test at $5 \%$ probability. Means followed by $\bullet$ differ from the initial time (fresh seeds) by Dunnett test at 5\% probability. W; F: statistics of Shapiro-Wilk and Levene's test respectively indicate residue with normal distribution and variance. $\mathrm{ns}=$ not significant.

Table 7. Total soluble sugars (TSS, $\mu$ mol. $\mathrm{mg}^{-1}$.fw) of $A$. cearensis seedlings' roots in different storage conditions and times of storage.

\begin{tabular}{|c|c|c|c|c|}
\hline \multirow[b]{2}{*}{$\begin{array}{l}\text { Time Storage } \\
\text { (Months) }\end{array}$} & \multicolumn{4}{|c|}{ Storage conditions } \\
\hline & $\begin{array}{l}\text { Airtight container in } \\
\text { Refrigerator }\end{array}$ & $\begin{array}{l}\text { Airtight container in } \\
\text { Laboratory }\end{array}$ & $\begin{array}{l}\text { Laboratory without } \\
\text { container }\end{array}$ & $\begin{array}{l}\text { Liquid nitrogen }\left(\mathrm{N}_{2}\right) \\
\text { container }\end{array}$ \\
\hline 0 & 392.8 & & & \\
\hline 6 & 503.6 Aab & $383.6 \mathrm{Aab}$ & $417.8 \mathrm{Aa}$ & $444.0 \mathrm{Aa}$ \\
\hline 9 & 457.6 Aa & $348.0 \mathrm{Bb}$ & $401.0 \mathrm{ABa}$ & 415.6 ABab \\
\hline 12 & 392.4 Aab & 410.0 Aab & $369.2 \mathrm{Aa}$ & $366.2 \mathrm{Aab}$ \\
\hline 21 & $360.0 \mathrm{Aab}$ & $335.8 \mathrm{ABb}$ & $311.6 \mathrm{ABa}$ & $284.8 \mathrm{Bb}$ \\
\hline 24 & $380.2 \mathrm{Ab}$ & $380.4 \mathrm{Aab}$ & $323.4 \mathrm{Aa}$ & $343.4 \mathrm{Aab}$ \\
\hline 27 & 448.6 Aab & $487.2 \mathrm{Aa}$ & $411.0 \mathrm{Aa}$ & $380.0 \mathrm{Aab}$ \\
\hline
\end{tabular}

$\mathrm{CV} \%=12.75 ; \mathrm{W}=0.98 \mathrm{~ns} ; \mathrm{F}=3.43 * *$

Means followed by the same capital letters in the line and lowercase on the column do not differ by Kruskal-Wallis ranking values at $5 \%$ probability. Means followed by $\bullet$ differ from the initial time (fresh seeds) by Kruskal-Wallis test at $5 \%$ probability. W; F: statistics of Shapiro-Wilk and Levene's test respectively indicate residue with normal distribution and variance. ns and $* *=$ not significant and significant at $1 \%$, respectively. 
Table 8. Reducing sugar (RS, $\mu$ mol.mg-1.fw) of $A$. cearensis seedlings' roots in different storage conditions and times of storage.

\begin{tabular}{|c|c|c|c|c|}
\hline \multirow{2}{*}{$\begin{array}{c}\text { Time Storage } \\
\text { (Months) }\end{array}$} & \multicolumn{4}{|c|}{ Storage conditions } \\
\hline & $\begin{array}{l}\text { Airtight container in } \\
\text { Refrigerator }\end{array}$ & $\begin{array}{l}\text { Airtight container in } \\
\text { Laboratory }\end{array}$ & $\begin{array}{l}\text { Laboratory without } \\
\text { container }\end{array}$ & $\begin{array}{l}\text { Liquid nitrogen }\left(\mathrm{N}_{2}\right) \\
\text { container }\end{array}$ \\
\hline 0 & 177.9 & & & \\
\hline 6 & •273.5 Aa & $185.4 \mathrm{Bab}$ & $229.6 \mathrm{ABa}$ & $228.2 \mathrm{ABbc}$ \\
\hline 9 & •246.3 Aab & $202.4 \mathrm{Aa}$ & •240.7 Aa & 207.2 Acd \\
\hline 12 & 158.2 Ad & 179.7 Aab & $153.7 \mathrm{Ab}$ & $156.9 \mathrm{Ad}$ \\
\hline 21 & 177.8 Bcd & $148.9 \mathrm{Bb}$ & $160.7 \mathrm{Bb}$ & •276.2 Aab \\
\hline 24 & 166.6 Bcd & $207.5 \mathrm{Ba}$ & $172.5 \mathrm{Bb}$ & •295.6 Aa \\
\hline 27 & $212.8 \mathrm{Abc}$ & $215.5 \mathrm{Aa}$ & $159.4 \mathrm{Bb}$ & -260.5 Aabc \\
\hline
\end{tabular}

Means followed by the same capital letters in the line and lowercase on the column do not differ by Tukey test at $5 \%$ probability. Means followed by $\bullet$ differ from the initial time (fresh seeds) by Dunnett test at 5\% probability. W; F: statistics of Shapiro-Wilk and Levene's test respectively indicate residue with normal distribution and variance. $\mathrm{ns}=$ not significant.

and demonstrated the capacity of survival even with high temperature and relative humidity ( $\mathrm{RH})$ oscillations based on the average daily oscillations. Therefore, A. cearensis seeds stored in airtight containers and, consequently without variations in $\mathrm{RH}$, were not influenced by daily temperature fluctuations and did not lose their viability. The laboratory seeds exposed to natural environment showed decreasing viability over time (Guedes et al., 2012). The laboratory seeds exposed to natural environment showed decreasing viability over time (Guedes et al., 2012). In laboratory conditions, the combination of high temperatures and RH can cause damage to $A$. cearensis seeds, by decreasing vigour and favouring the development of harmful microorganisms. In this way, only highly vigorous seeds are likely to survive.

The lower FG of seeds stored in liquid $\mathrm{N}_{2}$, after 24 months of storage, could be attributed to the time of withdrawal of the seeds from the $\mathrm{N}_{2}$ flasks to the refrigerator. The seeds were observed to have tissue disruption during thawing when they were removed from liquid $\mathrm{N}_{2}$ (Table 1).

Difference on the time between first and last $20 \%$ of germinated seeds (GU) as of the $12^{\text {th }}$ month in liquid $\mathrm{N}_{2}$ stored seeds compared with fresh seeds could be explained by the viability loss at low storage temperature. The low storage temperature induced greater germination uniformity with potentially delayed values that suggest a capacity for wide spread germination over time over by a natural need of survival of the species (Table 3). Notwithstanding the differences presented in relation to fresh seeds, the values obtained in $\mathrm{N}_{2}$ did not differ significantly from those in other treatments.

Amburana cearensis seeds had high viability with $90 \%$ of germination in the $27^{\text {th }}$ month for seeds stored in airtight containers in the laboratory and liquid $\mathrm{N}_{2}$ and showed low emergence for this same period in the field. FE was demonstrated to be a good test to determine the deteriorated or low seed vigour seed because the FE test is thinner (detectable) and easily determines the seed vigour of $A$. cearensis seeds. Many authors support the possibility of a relationship between emergence and seed vigour (Demir et al., 2008; Milošević et al., 2010; Perveen et al., 2010). For example, FE can also be used to separate accessions for use in reforestation and conservation.

Higher RH in the laboratory could be responsible for differences in vigour for the ER of seeds stored without containers, which may be influenced at the end of the storage period by the non-environmental control during the storage period (Table 5). Seed vigour is associated with the deterioration process (Shelar et al., 2008), which may have occurred in seeds stored in the laboratory outside of the airtight containers.

Reserve mobilization in the A. cearensis germinated seeds was directly influenced by the ultra-low storage temperatures (Tables 7 and 8). These results evidenced the mobilization of reserve compounds in the cotyledons (source) and their translocation to the root (drain) when the seeds were stored at low temperatures in the last 3 storage periods evaluated. Therefore, the selective mobilization of sugars at low temperatures can be highlighted, and their levels could be attributed to stress factors.

Storing seeds in airtight containers in a laboratory environment can maintain their quality for at least one year (Table 4). This allows the maintenance of high seed vigour until seedling production in nurseries for reforestation in the next rainy season. Seeds should be kept well preserved at least until the next season, which is the period when flowering generally occurs. Under laboratory environments, seeds typically lose their viability within months (Barbedo et al., 2002), and Caatinga 
seedlings can only be sown at a specific time (January to May) of soil water availability (Meiado et al., 2012). Therefore, these studies, through the response of germinability time, allow progress in our understanding of seed storage. Moreover, cryopreservation and defrosting techniques should be improved for this species.

\section{Conclusions}

It is not advisable to store $A$. cearensis seeds in a laboratory environment without airtight containers.

Amburana cearensis seeds kept in a refrigerated environment maintain their viability for at least two years.

Mobilization of reserve compounds is directly influenced when seeds are stored at low temperatures.

\section{Acknowledgements}

The authors would like to thank the CAPES / EMBRAPA (BEX 4133/14-5) and Fapesb scholarship, for all support during the production of this work.

\section{References}

AMERICAS REGIONAL WORKSHOP (Conservation \& Sustainable Management of Trees, Costa Rica, November 1996) 1998. Amburana cearensis. The IUCN Red List of Threatened Species. Version 2015.2. <www.iucnredlist.org >.

ARJMAND, H.S.; ABARGHOOEI, G.H.B.; GHORBANPOUR, M.; SHARAFI, S. Effect of zinc coated during storage on the seed quality of barley. International Journal of Farming and Allied Science, v.3, p.845-850, 2014. http://ijfas.com/wp-content/ uploads/2014/08/845-850.pdf

BARBEDO, C.J.; BILIA, D.A.; FIGUEIREDO-RIBEIRO, R.C. Tolerância à dessecação e armazenamento de sementes de Caesalpinia echinata Lam.(pau-brasil), espécie da Mata Atlântica. Revista Brasileira de Botânica, v.25, n.4, p.431-439, 2002. http://www.scielo. br/pdf/\%0D/rbb/v25n4/a07v25n4.pdf.

BIRUEL, R.P.; AGUIAR, I.B.; PAULA, R.C. Germinação de sementes de pau-ferro submetidas a diferentes condições de armazenamento, escarificação química, temperatura e luz. Revista Brasileira de Sementes, v.29, n.3, p.151-159, 2007. http://www. scielo.br/pdf/rbs/v29n3/a18v29n3

BRASIL, Ministério da Agricultura, Pecuária e Abastecimento. Instruções para análise de sementes de espécies florestais, de 17 de janeiro de 2013, Brasília: MAPA, 2013. 98 p. http://www.agricultura. gov.br/assuntos/insumos-agropecuarios/arquivos-publicacoes- insumos/2946_regras_analise_sementes.pdf

COSTA, R.C.; ARAUJO, F.S.; LIMA-VERDE, L.W. Flora and lifeform spectrum in an area of deciduous thorn woodland (caatinga) in northeastern, Brazil. Journal of Arid Environments, v.68, p.237-247, 2007. http://doi.org/10.1016/j.jaridenv.2006.06.003

DEMIR, I.; ERMIS, S.; MAVI, K.; MATTHEWS, S. Mean germination time of pepper seed lots (Capsicum annuum L.) predicts size and uniformity of seedlings in germination tests and transplant modules. Seed Science and Technology, v.36, n.1, p.21-30, 2008. https://doi.org/10.15258/sst.2008.36.1.02

FARIAS, A.A.; SILVA, M.J.; ALVES, T.L.B.; BARBOSA, M.P.; NETO, J.M.M. Análise das classes de cobertura vegetal no entorno do açude Manoel Marcionílo, Taperoá-PB (Class analysis of vegetation cover in surrounding the weir Manoel Marcionílo, Taperoá-PB). Revista Brasileira de Geografia Física, v.6, n.6, p.1719-1732, 2013. https://periodicos.ufpe.br/revistas/geografiafisica/article/view/12670

GALÍNDEZ, G.; MALAGRINA, G.; CECCATO, D.; LEDESMA, T.; LINDOW-LÓPEZ, L.; BAES, P.O. Dormición física y conservación ex situ de semillas de Amburana cearensis y Myroxylon peruiferum (Fabaceae). Boletín de la Sociedad Argentina de Botánica, v.50, n.2, p.153-161, 2015. http://www.scielo.org.ar/scielo.php?script=sci arttext\&pid $=$ S1851-23722015000200003

GUEDES, R. S.; ALVES, E.U.; GONÇALVES, E.P.; VIANA, J.S.; FRANÇA, P.R.C.; SILVA SANTOS, S. Qualidade fisiológica de sementes armazenadas de Amburana cearensis (Allemão) A.C. Smith. Semina: Ciências Agrárias, v.31, n.2, p.331-342, 2010. https://www.researchgate. net/profile/Roberta_Guedes/publication/46575897 Physiological quality_of_Amburana_cearensis_Allemao_AC_Smith_seeds_stored Qualidade_fisiologica_de_sementes_armazenadas_de_Amburana_ cearensis_Allemao_AC_Smith/links/564090d608aef2be8e-051696.pdf

GUEDES, R.S.; ALVES, E.U.; BRUNO, R.L.A.; GONÇALVES, E.P.; COSTA, E.G.; MEDEIROS, M.S. Armazenamento de sementes de Myracrodruon urundeuva Fr. All. em diferentes embalagens e ambientes. Revista Brasileira de Plantas Medicinais, v.14, n.1, p.6875, 2012. http://www.scielo.br/pdf/rbpm/v14n1/v14n1a10

LEAL, I.R.; SILVA, J.M.C.; TABARELLI, M.; LACHER-JR., T.E. Changing the course of biodiversity conservation in the Caatinga of Northeastern Brazil. Conservation Biology, v.19, n.3, p.701-706, 2005. 10.1111/j.1523-1739.2005.00703.x

LEIVAS, J.F.; ANDRADE，R.G.; CASTRO VICTORIA，D.; TORRESAN, F.E.; BOLFE, E.L. Monitoramento da seca 2011/2012 no nordeste brasileiro a partir do satélite spot-vegetation e trmm/ drought monitoring in 2011/2012 for the brazilian northeast based on the satellite spot-vegetation and trmm. Revista Engenharia na Agricultura, v.22, n.3, p.211-221, 2014. http://search.proquest. com/openview/eddd0926083d224dbeb3e94383b8b499/1?pqorigsite $=$ gscholar $\& \mathrm{cbl}=426377$

LIMA-ARAÚJO, E.; CASTRO, C.C.; ALBUQUERQUE, U.P. Dynamics of Brazilian Caatinga - A review concerning the plants, environment and people. Functional Ecosystems and Communities, v.1, n.1, p.15-28, 2007. https://www.researchgate. net/profile/Cibele_Castro2/publication/282363215 Dynamics of_Brazilian_Caatinga_-_A_Review_Concerning_the_Plants Environment and People/links/560e- $97 \mathrm{a} 608 \mathrm{ae} 0 \mathrm{fc} 513 \mathrm{ed} 8 \mathrm{~d} 5 \mathrm{e} /$ Dynamics-of-Brazilian-Caatinga-A-Review-Concerning-the- 
Plants-Environment-and-People.pdf

LOIOLA, M.I.B.; ROQUE, A.A.; OLIVEIRA, A.C.P. Caatinga: Vegetação do semiárido brasileiro. Revista Ecologi@: Artigos de Divulgação, v.4, p.14-19, 2012. http://speco.fc.ul.pt/revistaecologia_4. pdf\#page $=15$

LÚCIO, A.A.; ARAUJO, M.N.; SILVA, F.F.S.; DANTAS, B.F. Effect of storage in different environments and packages on germination of Amburana cearensis (Allemao) A. C. Sm. seeds. International Journal of Environment, Agriculture and Biotechnology (IJEAB), v.1, n.4, p.1037-1040, 2016. http://dx.doi.org/10.22161/ijeab/1.4.57

MAIA, G.N. Caatinga: árvores e arbustos e suas utilidades. São Paulo: Editora Leitura e Arte, 2008. 413p.

MEIADO, M.V.; SILVA, F.F.S.; CARVALHO, D.C.A.; SIQUEIRA FILHO, J.A. Diaspore of the caatinga: a review. Flora of the Caatingas of the São Francisco River: Natural History and Conservation. Rio de Janeiro: Andrea Jakobsson Estúdio Editorial, 2012. p.306-365.

MILLER, G.L. Use of dinitrosalicylic acid reagent for determination of reducing sugar. Analytical Chemistry, v.31, n.3, p.426-428, 1959. http://nsrdec.natick.army.mil/LIBRARY/59-69/R59-36.pdf

MILOŠEVIĆ, M.; VUJAKOVIĆ, M.; KARAGIĆ, Đ. Vigour tests as indicators of seed viability. Genetika, v.42, n.1, p.103-118, 2010. https://doi.org/10.2298/GENSR1001103M

MONCALEANO-ESCANDON, J.; SILVA，B.C.; SILVA, S.R.; GRANJA, J.A.; ALVES, M.C.J.; POMPELLI, M. F. Germination responses of Jatropha curcas L. seeds to storage and aging. Industrial Crops and Products, v.44, p.684-690, 2013. http://doi.org/10.1016/j. indcrop.2012.08.035

MORRIS, D.L. Quantitative determination of carbohydrates with Dreywood's anthrone reagent. Science, v.107, p.254-255, 1948. https://www.ncbi.nlm.nih.gov/ pubmed/17814729

NASCIMENTO, W.M. (Org.). Tecnologia de sementes de hortaliças. Brasília, DF: Embrapa Hortaliças, 2009. 432 p.

OLIVEIRA, L.M.; BRUNO, R.L.A.; SILVA, K.R.G.; ALVES, E.U.; SILVA, G.Z.; ANDRADE, A.P. Qualidade fisiológica de sementes de Caesalpinia pyramidalis Tul. armazenadas. Journal of Seed Science, v.33, n.2, p.289-298, 2012. http://submission.scielo.br/index.php/jss/ article/view/36619

PERVEEN, S.; NIGAR, S.; KHALIL, S.; ZUBAIR, M. Vigor tests used to rank seed lot quality and predict field emergence in wheat.
Pakistan Journal of Botany, v.42, n.5, p.3147-3155, 2010. DOI: 10.3923/ajpp.2007.311.317

PIMENTEL, J.V.F.; GUERRA, H.O.C. Semiárido, caatinga e legislação ambiental. Prima Facie-Direito, História e Política, v.8, n.14, p.104-126, 2010. http://www.biblionline.ufpb.br/ojs2/index. php/primafacie/article/view/4372

PRITCHARD, H.W.; NADARAJAN, J. Cryopreservation of orthodox (desiccation tolerant) seeds. In Plant Cryopreservation: A Practical Guide (pp. 485-501). Springer New York. 2008. DOI 10.1007/978-0-387-72276-4 19

SANTOS, J.C.; ALMEIDA-CORTEZ, J.S.; FERNANDES, G.W. Diversity of gall-inducing insects in the high altitude wetland forests in Pernambuco, Northeastern Brazil. Brazilian Journal of Biology, v.71, n.1, p.47-56, 2011. http://dx.doi.org/10.1590/S151969842011000100008

SANTOS, M.V.F.D.; LIRA, M.D.A.; JUNIOR, D.; BATISTA, J.C.; GUIM, A.; MELLO, A.C.L.D.; CUNHA, M.V.D. Potential of Caatinga forage plants in ruminant feeding. Revista Brasileira de Zootecnia, v.39, p.204-215, 2010. http://dx.doi.org/10.1590/S151635982010001300023

SHELAR, V.R.; SHAIKH, R.S.; NIKAM, A.S. Soybean seed quality during storage: a review. Agricultural Reviews, v.29, n.2, p.125-131, 2008. http://www.arccjournals.com/uploads/articles/ar292006.pdf

TOOROP, P.E.; CUERVA, R.C.; BEGG, G.S.; LOCARDI, B.; SQUIRE, G.R.; IANNETTA, P.P. Co-adaptation of seed dormancy and flowering time in the arable weed Capsella bursa-pastoris (shepherd's purse). Annals of Botany, v.109, p.481-489, 2012. https://doi.org/10.1093/aob/mcr301

TROVÃO, D.M.B.M.; FERNANDES, P.D.; ANDRADE, L.A.; NETO, J.D. Variações sazonais de aspectos fisiológicos de espécies da Caatinga. Revista Brasileira de Engenharia Agrícola e Ambiental, v.11, n.3, p.307-311, 2007. http://www.scielo.br/pdf/rbeaa/v11n3/ a10v11n 3

YEMM, E.W.; WILLIS, A.J. The estimation of carbohydrates in plants extracts by anthrone. Biochemistry Journal, v.57, p.508-514, 1954. https://www.ncbi.nlm.nih.gov/pmc/articles/PMC1269789/

ZUCHI, J.; FRANÇA-NETO, J.B.; SEDIYAMA, C.S.; LACERDA FILHO, A.F.D.; REIS, M.S. Physiological quality of dynamically cooled and stored soybean seeds. Journal of Seed Science, v.35, n.3, p.353-360, 2013. http://dx.doi.org/10.1590/S2317-15372013000300012 